\title{
THE SIZE OF PLAZAS IN MESOAMERICAN CITIES AND TOWNS: A QUANTITATIVE ANALYSIS
}

\author{
Alanna Ossa, Michael E. Smith, and José Lobo
}

\begin{abstract}
We present quantitative data on population size and plaza area in three groups of ancient Mesoamerican settlements: a sample of 30 Late Postclassic cities and towns from throughout Mesoamerica and two regional settlement systems from the Classic period, including south-central Veracruz (the Mixtequilla) and the Palenque region. Plaza size scales with population in a sublinear relationship in all three groups, meaning that larger settlements had considerably less plaza area per capita than smaller settlements. These results suggest that the currently popular interpretation drawn from Classic Maya archaeology that plazas were places designed to hold the entire urban population for passive viewing of spectacles may be incomplete. We argue that the observed quantitative relationships between population and plaza area support the notion that plazas were designed to be used for a variety of purposes_including several types of ceremonies and marketplaces-held at different times following a regular schedule.
\end{abstract}

Presentamos datos cuantitativos sobre el tamaño de la población y el área de la plaza en tres grupos de antiguos asentamientos Mesoamericanos: una muestra de 30 ciudades y pueblos del período Posclásico Tardío de toda Mesoamérica y dos sistemas de asentamientos regionales del período Clásico, incluyendo el sur-central de Veracruz (La Mixtequilla) y la región de Palenque. El área de la plaza varía con respecto al tamaño de la población en una relación sublineal en los tres grupos. Los datos sugieren que los asentamientos mayores tenían considerablemente menos área de plaza per cápita que los asentamientos más pequeños. Los resultados de este estudio demuestran que la interpretación actualmente popular, del período Clásico Maya, de las plazas como lugares creados para sostener a toda la población urbana para la visión pasiva de los espectáculos, puede ser incompleta. Argumentamos que las relaciones cuantitativas observadas entre la población y el área de la plaza apoyan la idea de que estas últimas fueron creadas a fin de ser usadas para una variedad de propósitos -incluyendo varios tipos de ceremonias y mercados - en diferentes momentos siguiendo un horario regular.

$\mathrm{N}$ early every ancient Mesoamerican city known to archaeologists has one or more formal public plazas, typically in the epicenter/central zone. These are often large, impressive spaces, ringed by tall pyramids and other civic buildings. Scholars of Mesoamerican urban form have identified the plaza as one of the fundamental elements of urban planning in the area (e.g., Andrews 1975:37). Archaeologists have had difficulty, nevertheless, determining with confidence what activities took place in these plazas. Plazas were probably cleaned after they were used, leaving few direct artifactual traces of their function. In this article, we examine the size of Mesoamerican plazas relative to the overall population of the settlements in which they occur to determine their ancient use.

Within a given Mesoamerican urban tradition such as the Classic Maya or the Aztec, informal observation suggests that larger cities and urban settlements tend to have larger central plazas or greater total plaza area, sometimes distributed among more than one formal plaza (Andrews 1975; Inomata 2006a; Smith 2008). But do larger

\footnotetext{
Alanna Ossa - Department of Anthropology, State University of New York at Oswego, 7060 State Route 104, Oswego, NY 13126, USA (alanna.ossa@ oswego.edu; corresponding author)

Michael E. Smith $\square$ School of Human Evolution and Social Change, Arizona State University, 900 South Cady Mall, Tempe, AZ 85281, USA (mesmith9@asu.edu)

José Lobo - School of Sustainability, Arizona State University, 800 South Cady Mall Tempe, AZ 85281, USA (jose.lobo@asu.edu)
}

Latin American Antiquity 28(4), 2017, pp. 457-475

Copyright (C) 2017 by the Society for American Archaeology doi:10.1017/laq.2017.49 
cities have more, less, or the same amount of plaza space per person compared to smaller cities? This relationship is interesting because important activities with few direct traces — such as rituals and markets-took place in plazas, and the relationship between settlement population and plaza area can give us insights into those activities. This quantitative relationship has not previously been investigated systematically. Is there a regular relationship between urban population and plaza size? And if so, can the form of the relationship help distinguish the likely uses of plazas? We present three independent sets of data that furnish a positive answer to both questions.

The expectation that larger settlements will have larger plazas - or more total plaza spaceis based on the following logic. Plazas were places where people gathered periodically, and these gatherings were most likely events that held significance - both personal significance for individual participants and social significance for urban society. Settlements with larger populations would therefore need more plaza space in order for the events in plazas to accommodate a greater number of participants. We limit consideration to formal public plazas; that is, built spaces with a clear spatial structure that were likely designed for human activity and interaction (see Smith 2007 on the concept of formal built spaces). We identify plazas as open spaces clearly oriented toward civic buildings, at least two sides of which are clearly delimited by architectural constructions. We focus here on public plazas, not residential patios.

The proposal that larger cities should have more plaza area makes sense in terms of a growing literature-in economics, economic geography, anthropology, and sociology - that suggests that the scale of human organizations and aggregations has a major effect on the performance of such population aggregations in public spaces (e.g., Bettencourt 2013; Carneiro 2000; Glaeser et al. 2003). Human settlements can be described as social networks that are embedded in physical space. In the words of architectural historian Spiro Kostof (1991:37), "cities are places where a certain energized crowding of people takes place." Face-to-face interaction is the foundation of social life in cities, from the ancient world to the present. Public spaces play a fundamental role in facilitating such interactions and may be expected to reflect some of their intensity and value. The size of plazas should thus be sensitive to the scale of social interaction, which in turn is a function of the population of a settlement.

We test these expectations by comparing plaza area and city population in three sets of Mesoamerican settlements: a sample of 30 Late Postclassic cities and towns from throughout Mesoamerica, a regional group of Classic period settlements from south-central Veracruz, and settlement pattern data from the Palenque region. In Mesoamerica, formal plazas were present not only in large capital cities but also in smaller settlements that could be called towns or even villages. Each of our three sets of sites contains urban centers (as defined in functional terms by Smith [2007]), meaning those that had ritual and administrative functions, and smaller settlements. The relationships we identify thus cut across the urban/nonurban distinction, and they describe settlement systems. We find that the three cases share a similar quantitative relationship between population size and plaza area, known as a "sublinear" scaling relationship. In other words, larger settlements have more plaza space, but less plaza space per capita, than smaller settlements. This finding reveals a decreasing proportion of the city population gathered in plazas at any given moment and suggests that a currently popular interpretation of Mesoamerican plaza construction and use-that they were designed specifically as settings for mass spectator ceremonies_-should be adjusted to take this general pattern into account.

\section{The Uses of Plazas in Mesoamerican Settlements}

The most extensive discussion of the uses and sizes of plazas in Mesoamerica concerns Classic (AD 250-900) Maya cities. We first review Takeshi Inomata's interpretation of Maya plazas, and then we outline the major types of direct and indirect evidence for plaza use in Mesoamerica. This section concludes with a discussion of five types of activities that likely took place in plazas: private rituals, periodic markets, mass spectator rituals, participatory public ceremonies, and feasts and other popular celebrations. 


\section{Classic Maya Plaza Size and Use}

In an influential paper, Takeshi Inomata (2006a) argued that plazas in Maya cities were "political theaters" where city residents gathered to witness theatrical performances by kings and elites. These were "large-scale performances involving a substantial number of participants" (Inomata 2006a:807). This argument originated with the notion that political power in Maya polities was based on spectacle and performance (Demarest 1992; Inomata 2006b), a model originally called the "theater state" by Clifford Geertz (1980). In this model, it is crucial that the entire populace is able to gather to witness royal spectacles. Inomata describes the implications of the theater state model for plazas as follows:

Yet the most important implication of these histories of plazas is that securing sufficient spaces for public events was a primary concern in the design of Maya cities. This means that plazas were meant to accommodate a large number of individuals and such gatherings were extremely important for Maya polities. Plazas and causeways were not secondary spaces defined after the placement of temple pyramids but social spaces of extreme importance in their own right. ... I argue that the critical elements that held together this precarious integration of Maya communities were the mass theatrical events sponsored and organized by the elite. Mass spectacles, in which a large portion of a community assembled and worked together, provided opportunities for individuals to witness and sense the bodily existence and participation of other members [Inomata 2006a:818].

Inomata analyzes the number of people that could fit in plazas by multiplying the area of urban plazas by several density constants reported by Jerry Moore (1996). He selects three figures mentioned by Moore-0.46, 1.00, and $3.60 \mathrm{~m}^{2}$ per person-and calculates the potential sizes of the groups that could fit into the plazas at Tikal, Copan, and Aguateca (Inomata 2006a:816). He compares these figures to the estimated populations of the three sites and concludes that the entire populations of Tikal, Copan, and Aguateca could have gathered in their respective plazas, although he admits that the entire population of Tikal would make for a tight fit, and the ceremonial plaza of Copan would not have provided the best sightlines (Inomata 2006a:813-814, Table 1). Despite these complications, Inomata concludes that for smaller and medium centers, the plazas would have held the majority of community members for politically charged ceremonies and that the large plazas of the large centers were made to hold large numbers of people. Even as fitting the entire population became difficult over time for the larger centers, accommodation was made to afford everyone access to mass spectacles (Inomata 2006a:819).

The density constants reported in Moore (1996:147) are rough estimates based on a small number of heterogeneous settlements, some reported by personal communications rather than publications. Inomata (2006a:812) acknowledges the provisional nature of these estimates. Nevertheless, this approach-estimating plaza occupancy based on $0.46,1.00$, and $3.60 \mathrm{~m}^{2}$ per person in support of mass spectator ceremonies as the cause of plaza size-has been taken up by other Mayanists and other Mesoamericanists (Robin et al. 2014:381; Tsukamoto and Inomata 2014) and North Americanists (Cobb and Butler 2017; Thompson 2009). The use of these plaza size constants suggests that these authors-like Inomata-assume that the entire urban population would have gathered in the plazas. ${ }^{1}$

The basic assumption of Inomata's model of mass spectator ceremonies is that the entire population of a settlement (or a polity) could fit into the plazas of a capital to witness ceremonies. If this model is correct, we should expect a linear relationship between city population and plaza area. Our data, however, reveal a relationship inconsistent with this interpretation. The relationship between population and plaza size is sublinear when the variables are expressed as logarithms, which means that larger settlements have considerably less plaza space per capita than smaller settlements.

\section{Sources of Evidence}

Aztec Ethnohistory. Most written descriptions of activities that likely took place in Aztec plazas-market activities, state ceremonies, and 
public gatherings- pertain to the imperial capital Tenochtitlan. One divergent feature of the layout of Tenochtitlan is the large size and enclosed configuration of the central plaza. An open plaza similar to most city-state capitals may have been present early in the history of the city, but as imperial expansion proceeded, a wall was built enclosing the entire central zone (the so-called sacred precinct). This area was filled with shrines, altars, and other buildings (Rojas 2012:56-64), although considerable open gathering space remained between the buildings.

Mesoamerican Ethnography. Markets and commercial exchange were widespread in Mesoamerica at the time of the Spanish conquest (Berdan et al. 2003), and most scholars acknowledge a continuity from this pre-Spanish pattern to the markets described by ethnographers in peasant villages of twentieth-century Mexico (Hassig 1985). This information provides relevant analogies for marketplaces in plazas.

Soil Chemistry. Archaeologists have used chemical analyses of sediments from plazas to infer the activities that may have taken place. Suggestions include food preparation, feasting, rituals involving incense, and market activity (e.g., Canuto et al. 2010; Dahlin et al. 2007; Fulton et al. 2017; Terry et al. 2015). Unfortunately, the number of ethnographic analogues is still too small and unsystematic to establish reliable signatures for individual activities. An increase in the number of contemporary analogues would permit better testable predictions for alternative plaza uses.

Other Direct Archaeological Evidence. Because plazas were probably kept relatively clear of debris, direct archaeological evidence for their use can be difficult to find. In one study, Cap used microartifact distributions and other archaeological data from the Classic Maya site of Chan to infer three types of likely plaza activities: "(1) political/religious ceremonies, (2) economic transactions, and (3) social gatherings" (Cap 2012:152). Chase and colleagues (2015) also used multiple types of evidence to infer marketplaces in formal open spaces at Caracol. Carballo (2012) has interpreted buried offerings and geophysical prospecting results as suggesting differential use of two plazas at the Formative period site of La Laguna: public religious ceremonies in a more formal plaza, and feasting and more informal public activities in an adjacent, less formal plaza. Masson and Friedel (2013) used distributional patterns of artifacts to infer the presence of markets in plazas.

\section{Plaza Activities}

On the basis of the above sources of evidence we identify five types of activities that likely took place in Mesoamerican urban plazas: private rituals, periodic markets, mass spectator ceremonies, participatory public ceremonies, and feasts and other popular celebrations.

Private Rituals. We use the term private ritual here to refer to ritual activities carried out by a small number of participants and not witnessed by others. Aztec sources describe many such private rituals - such as bloodletting and incense burning-carried out by priests and novices (Durán 1971), although their spatial locations are rarely indicated. Carballo (2012) interprets a plaza deposit of greenstone objects at La Laguna, perhaps dispersed by a ritual scattering activity, as a possible case of private ritual in a plaza.

Periodic Markets. In most contemporary peasant societies with active and widespread commercial exchange, marketplaces are periodic. Towns may have permanent markets in dedicated buildings that are open daily while smaller settlements typically host a weekly market. Towns with permanent market buildings typically have a weekly "market day" when stalls and exchange activity expand beyond the market building into nearby streets and plazas (Cook and Diskin 1976).

As the location of one of the best-described premodern markets in the world, the Aztec island capital Tenochtitlan/Tlatelolco provides considerable information about marketplaces relevant to other, earlier Mesoamerican cities. Tlatelolco, where the conqueror Cortés described 60,000 daily attendees at the market, had the only welldocumented case of a dedicated marketplace building of any Aztec city. This was located adjacent to the main public plaza of Tlatelolco (Díaz 
del Castillo 1956:217; González Rul 1998). In the Maya area, Christopher Jones (2015) has made a strong case for the existence of a market building (an enclosed compound with stalls) at Tikal.

For the city of Tenochtitlan, there is limited historical evidence to suggest that a market was held in a plaza outside the royal palace (Matos Moctezuma 2015). Scattered records suggest strongly that all Aztec cities hosted periodic markets (Blanton 1996; Smith 2012:Chapter 5), and the absence of market buildings at smaller Aztec cities (Smith 2008) lends support to the notion that the weekly markets were held in the formal plaza of each city.

The strongest direct evidence for marketplace activities in an urban plaza comes from Chunchucmil. Dahlin and colleagues measured the concentrations of phosphates and other compounds in domestic contexts, likely ceremonial plazas, and a less formal plaza (Dahlin et al. 2007). They compared the results to soil data gathered at a contemporary highland Maya marketplace to identify a likely market plaza at Chunchucmil.

Mass Spectator Ceremonies. We define a mass spectator ceremony as a large crowd gathered in one space to witness or participate together in a royal or state ceremony. For the Aztecs, the works of Friar Diego Durán are full of passages that mention or imply the presence of large crowds gathered in plazas to witness events. Here are some of Durán's (1971) remarks about various monthly ceremonies in Tenochtitlan (note that these quotations describe different ceremonies): "While they [the participants in a sacrifice] were ascending, all the people stood below in the courtyard with great reverence and awe" (88); "This performance was attended by the entire city" (104); "The entire city was present at this spectacle" (180). In these passages, Durán uses the term "courtyard" to refer to the open space in front of and surrounding the main temple of Tenochtitlan, within the sacred precinct.

Participatory Public Ceremonies. A participatory public ceremony is an event in which groups of people participate in specific movements and activities in designated locations.
The Aztec monthly ceremonies, as described by Sahagún and others, provide many examples. Plazas were the settings for processions, dances, sacrifices, and offerings of incense. The Codex Borbonicus, for example, shows an Aztec urban plaza (Figure 1) that corresponds closely to the known layouts of many Aztec cities (Smith 2008:127-132). A group of deity impersonators (ixiptla) lines the edges of the plaza, suggesting that the plaza was used for public religious ceremonies.

The Primeros Memoriales of Sahagún (1993) contains paintings of the 18 state-sponsored monthly ceremonies, described in detail in Book 2 of the Florentine Codex (Sahagún 19501982). The painting of the Tlacaxipeualiztli ceremony (Figure 2) includes two buildings and three shrines or altars, around which six different groups of actors are engaged in various activities, including human sacrifice, playing musical instruments, and formal processions. No spectators are depicted; each person participates in a specific, localized ritual activity. Diverse groups of people were engaged in active participation, visible to anyone who cared to look. Mass spectator ceremonies by contrast have larger crowds, packed more tightly together, whose members passively witness staged events or may participate together in activities that do not require extensive space, such as chanting or limited choreographed movement.

Feasts and Other Popular Celebrations. We are unaware of analogical data from Aztec or modern ethnographic sources pointing to feasting activities in plazas. Nevertheless, this is a common post hoc interpretation of soil chemistry results that suggest possible food preparation and consumption activities in Mesoamerican plazas (Canuto et al. 2010; Fulton et al. 2017). Feasting is a difficult plaza activity to document, since food preparation and consumption were likely components of several other plaza activities besides feasting.

\section{Multiple Activities Separated in Time}

The three most likely activities for Mesoamerican plazas-markets, participatory ceremonies, and mass spectator ceremonies-were all episodic in time, with regular dates in the calen- 


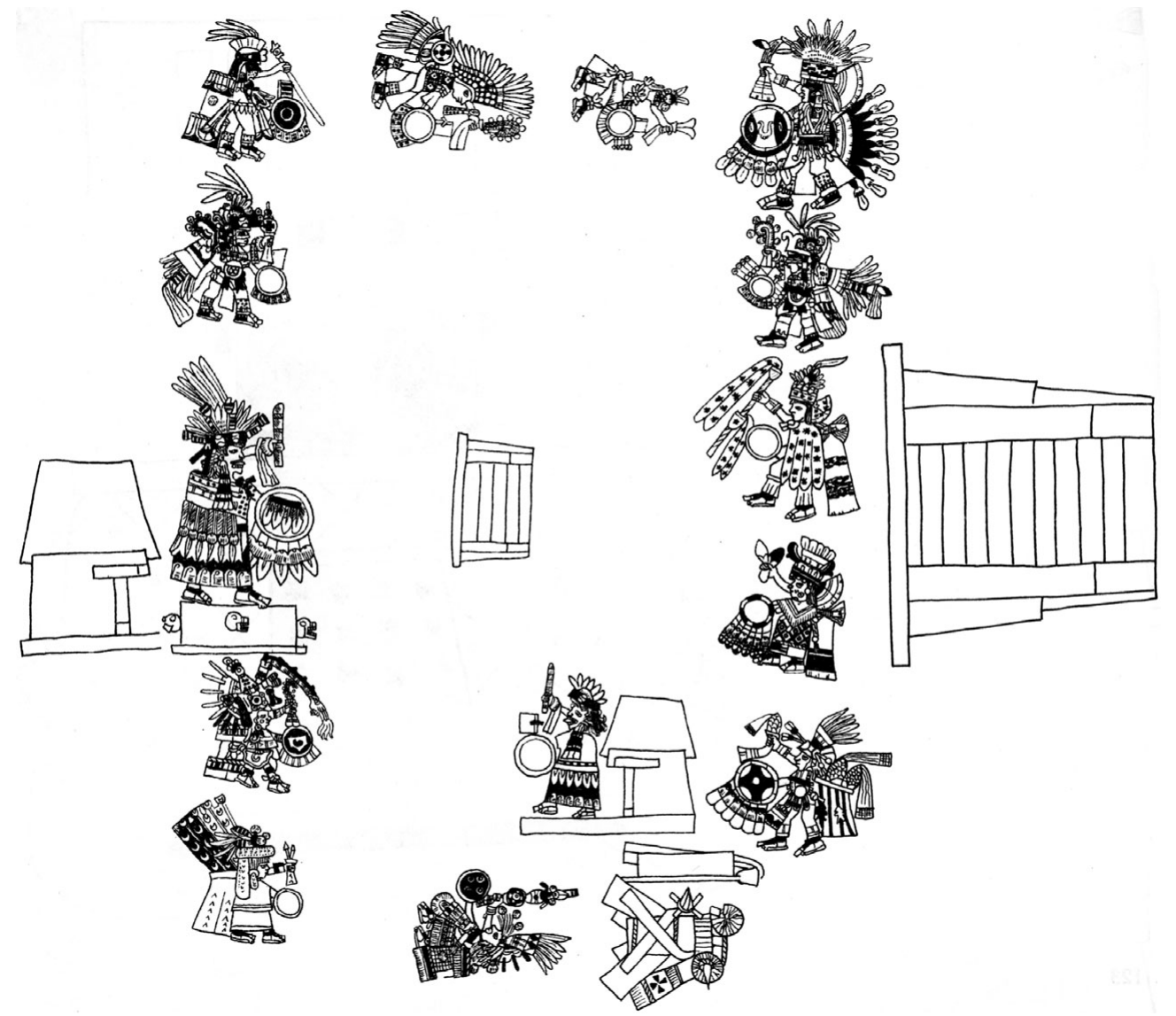

Figure 1. Aztec plaza with deity impersonators (ixiptla). We have rotated the image so that north is at the top. Redrawn from the Codex Borbonicus (Anders et al. 1991:36).

dars of known Mesoamerican societies. Among the Aztecs, for example, markets met weekly (every five days) and participatory ceremonies and mass ceremonies monthly (every 20 days). As such it would have been convenient to use formal plazas for all three kinds of activity, instead of creating separate spaces for each. This suggestion illustrates a key insight of environmentbehavior theory (Smith 2011), which posits that "organization in time may be substituted for organization in space" (Rapoport 1990:15).

The Mesoamerican ethnographic data provide insight into the nature of periodic uses of public plazas. Many indigenous towns have a central town square with a public fountain. Each week a market is held in the square, which remains empty the rest of the week. This pattern of a central square, which resembles a vacant lot most of the time but springs to life for market day, has been described by ethnographers of peasant villages in Oaxaca, western Guatemala, and other regions of Mesoamerica (e.g., Beals 1975; McBryde 1947). For example, in the late twentieth century, the Mexican town of Tepoztlan, Morelos (Lewis 1951), had a permanent market building adjacent to the town square. Most days the square was used for informal socializing and was frequently empty. But on market day (Sunday), the market spilled out of the market hall and temporary stalls covered the plaza (Figure 3). The multifunctional character of plazas in Latin American towns has been emphasized by Daniel Gade (1976) with respect to six types of plaza use: as an unimproved site, a marketplace, a ceremonial center, a social concourse, a garden park, and a traffic hub. The common factor among the diverse periodic activities that likely took place in plazas is that 


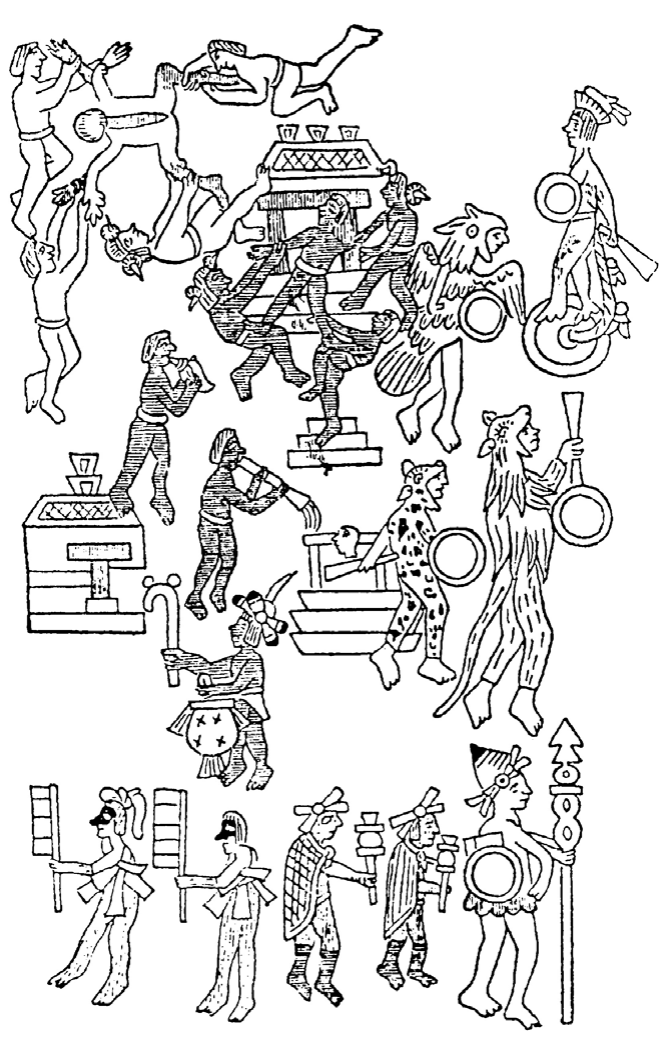

Figure 2. The Aztec monthly ceremony of Tlacaxipeualiztli from the Primeros Memoriales of Sahagún, modified after Seler (1927).

they all involve social interactions among large numbers of urban residents.

\section{Plaza Area and Population Size}

\section{Analytical Approach}

Our approach to plaza size differs from traditional analyses by Mesoamerican archaeologists. In that scholarly tradition, archaeologists commonly use excavation data to construct detailed analyses of individual architectural features like plazas. Although comparisons may be made among sites, such comparisons are typically peripheral to the major thrust of the study. Our approach, in contrast, is explicitly comparative and statistical in nature. Any comparative analysis requires simplification and abstraction. Instead of dealing with the specific stratigraphic sequences of individual plazas, we are comparing one variable — plaza size — across three groups of settlements in relation to their estimated population. In this manner, we evaluate plaza use by considering its area in relation to its surrounding settlement population.

\section{Estimation Framework}

We hypothesize that - within individual regions or urban systems - there was a systematic relationship between the area allocated to plazas and the population size of prehispanic Mesoamerican settlements. There are various possibilities as to the quantitative relationship between plaza area and population size, specifically with regard to how plaza areas changed in response to increases in population size: proportionally, for example, or less than proportionally. We adopt power-law function to represent the relationship between settlement population and plaza area:

$$
Y_{t}=Y_{0} N_{t}^{\beta},
$$

where $Y$ refers to total area of plazas, $N$ denotes population size, $Y_{0}$ is a prefactor (or constant) capturing the effects of technology and institutional arrangements on the relationship between population size and plaza area, and $t$ is a subscript identifying a particular time. The value of the exponent $\beta$ (an elasticity index) determines how the area of urban settlements allocated to plazas varied with settlement population within a settlement system. The choice of a power-law function assumes that the effect on plaza area of increasing population size is not additive but multiplicative, which is to say that the increase in plaza area is driven by the interaction of many factors observationally summarized in an increase in population size (Coffey 1979).

Adopting a power-law functional form carries another implication; namely, that the relationship between plaza area and population size is parametrized by a single number, $\beta$, which is itself scale independent. As a consequence, the rate of change or growth (in this case represented by the increase in the population size of settlements within a coherent system) is a constant fraction of the relative change in population. If empirically robust, such a regularity is a hint that indeed there were underlying socioeconomic and cultural processes that generated and maintained the same relationship among two structural and 


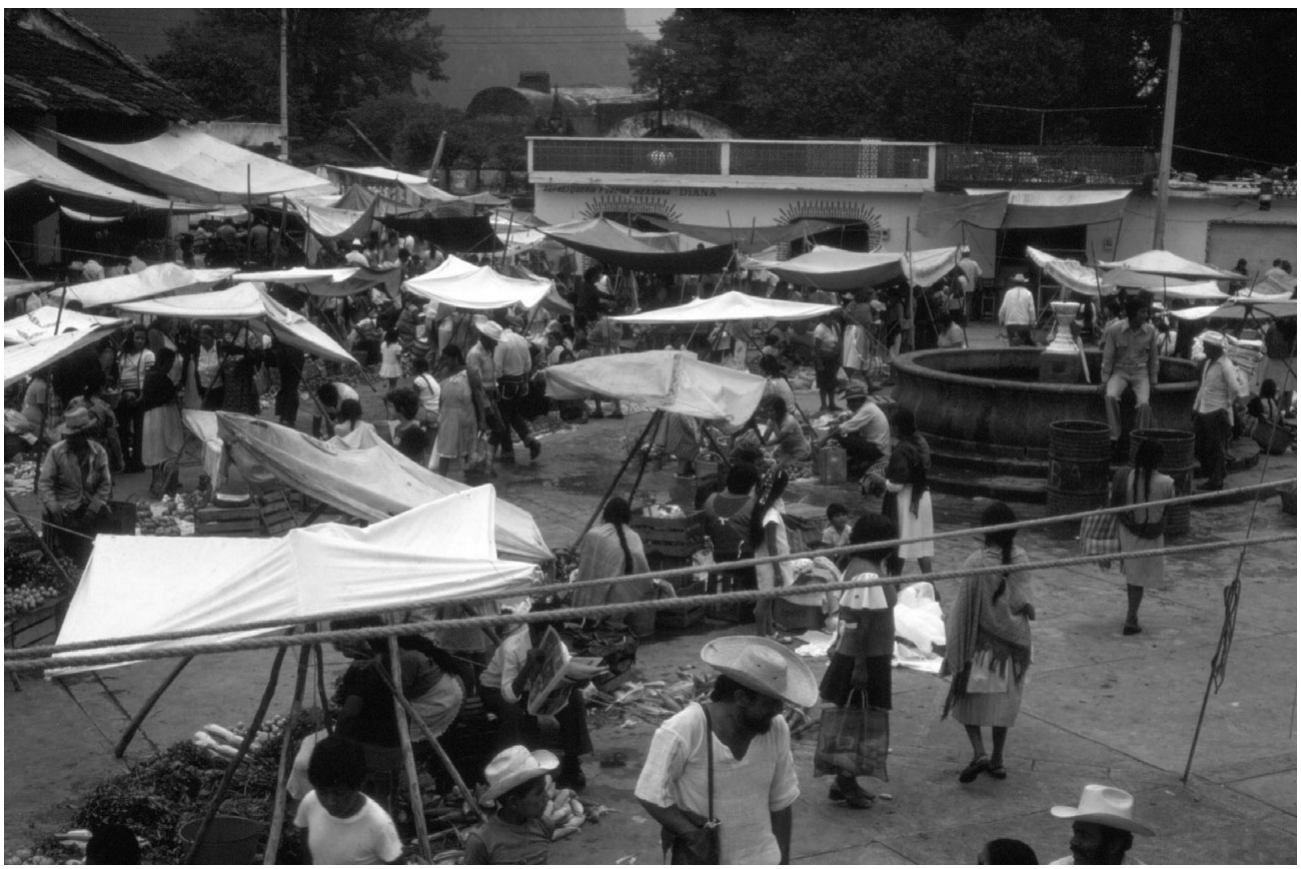

Figure 3. Temporary market stalls in the main plaza of the village of Tepoztlan, Morelos, Mexico, on a typical market day in 1980. Photograph by Michael E. Smith.

functional variables, plaza area and population, over the range of scales found within a settlement system (Brown et al. 2000). As suggested by Chave and Levin (2003:551), "scaling concepts offer an avenue to study heterogeneous assemblies for which the microscopic processes are not known, and probably not knowable (e.g., in the case of social systems) except in terms of their statistical properties." Thus, a scaling relation is perhaps the best evidence for the existence of general features in the immensely complex dynamics of social and economic systems (Brock 1999).

Taking the natural logarithm of Equation (1) we obtain a simple linear regression equation:

$$
\ln Y_{t}=c+\beta \ln N_{t}+\varepsilon_{t},
$$

in which $\varepsilon$ is an IID noise term (Gaussian white noise). Whether or not it is reasonable to adopt the assumptions carried along by the choice of a power-law functional form can be evaluated by performing the usual goodness-of-fit tests on Equation (2). The values for the $\beta$ coefficients reported in the present discussion were estimated for all three data sets using ordinary least squares (OLS) regression with a correction for heteroscedasticity (the estimations were done using the Stata 12SE software package). Note that our three steps - the choice of a power-law functional form, estimation of the scaling coefficients, and provision of a model or explanation for the estimated coefficient values-are distinct analytical exercises.

\section{Late Postclassic Mesoamerican Settlements}

Our first set of observations is drawn from a sample of Late Postclassic Mesoamerican settlements whose size and demography were analyzed previously by Smith (2005). The 2005 sample consisted of all Late Postclassic towns or cities with published detailed maps of their total extent, their urban epicenter, or both. Smith returned to that sample with Alexandra Norwood and measured the sizes of mapped plazas in all sites with adequate maps, yielding a sample of 22 sites. He then located eight additional sites fitting these criteria that were published after the data for the 2005 paper were collected. The sites are listed in Table 1 . They are organized by region 
Table 1. Population and Plaza Area of Late Postclassic Settlements.

\begin{tabular}{|c|c|c|c|c|c|c|c|c|c|}
\hline \multirow[b]{2}{*}{ Code } & \multirow[b]{2}{*}{ Site $^{b}$} & \multicolumn{2}{|c|}{ Site Area } & \multicolumn{2}{|c|}{$\begin{array}{l}\text { Population } \\
\text { Estimates }^{\mathrm{a}}\end{array}$} & \multirow{2}{*}{$\begin{array}{l}\text { No. of } \\
\text { Plazas }\end{array}$} & \multicolumn{2}{|c|}{$\begin{array}{c}\text { Plaza } \\
\text { Area }\left(\mathrm{m}^{2}\right)\end{array}$} & \multirow{2}{*}{$\begin{array}{l}\text { Plaza Area } \\
\text { per Capita }\end{array}$} \\
\hline & & ha. & Source $^{\mathrm{c}}$ & 1 & 2 & & Main Plaza & $\overline{\text { All Plazas }}$ & \\
\hline \multicolumn{10}{|c|}{ Central Mexico } \\
\hline $\mathrm{C} 02$ & Calixtlahuaca & 264.0 & M2 & 12,936 & 12,936 & 6 & $\mathrm{e}$ & 22,162 & 1.7 \\
\hline $\mathrm{C} 05$ & Cuexcomate* & 15.0 & $\mathrm{P} 1$ & 735 & 800 & 2 & 2,672 & 2,976 & 3.7 \\
\hline $\mathrm{C} 16$ & Venta Salada & 100.0 & M1 & 4,900 & 3,863 & 3 & $\mathrm{e}$ & 6,355 & 1.6 \\
\hline $\mathrm{C} 19$ & Tenochtitlan* & 1365.0 & $\mathrm{P} 1$ & 212,500 & 212,500 & 6 & 115,000 & 133,700 & 0.6 \\
\hline $\mathrm{C} 25$ & Coatlan Viejo & 15.0 & $\mathrm{P} 1$ & 735 & 367 & 1 & 2,361 & 2,361 & 6.4 \\
\hline $\mathrm{C} 26$ & Ixtapaluca Viejo & 90.0 & $\mathrm{P} 1$ & 4,410 & 3,390 & 1 & 3,354 & 16,081 & 4.7 \\
\hline \multicolumn{10}{|c|}{ Gulf Coast } \\
\hline G02 & Zempoala & 220.0 & $\mathrm{P} 1$ & 10,780 & 10,274 & 1 & 48,088 & 48,088 & 4.7 \\
\hline G04 & El Tigre & 500.0 & $\mathrm{P} 1$ & 24,500 & 28,448 & 2 & 33,917 & 49,604 & 1.7 \\
\hline G06 & Quauhtochco & 4.1 & $\mathrm{P} 2$ & 201 & 73 & 1 & 1,487 & 1,487 & 20.4 \\
\hline G07 & Tamohi & 200.0 & $\mathrm{P} 2$ & 9,800 & 9,128 & 1 & 7,015 & 7,015 & 0.8 \\
\hline G13 & Cotaxtla & 185.0 & $\mathrm{P} 1$ & 9,065 & 8,287 & 1 & 3,271 & 3,271 & 0.4 \\
\hline $\mathrm{G} 22$ & Totogal & 54.2 & $\mathrm{~A} 2$ & 2,656 & 1,807 & 1 & 8,521 & 8,521 & 4.7 \\
\hline \multicolumn{10}{|c|}{ Southeastern Mesoamerica } \\
\hline H04 & Utatlan & 200.0 & $\mathrm{P} 1$ & 9,800 & 9,128 & 2 & 5,577 & 6,806 & 0.7 \\
\hline H07 & Iximche & 3.8 & M2 & 186 & 67 & 4 & 2,852 & 10,711 & 159.9 \\
\hline H08 & Chisalin & 3.4 & M2 & 167 & 58 & 1 & 1,658 & 1,658 & 28.6 \\
\hline $\mathrm{H} 10$ & Acapetahua & 23.0 & M1 & 1,127 & 624 & 2 & 3,052 & 6,165 & 9.9 \\
\hline H11 & Cahyup & 12.0 & M1 & 588 & 278 & 4 & 1,840 & 4,121 & 14.8 \\
\hline H13 & Cawinal & 14.0 & M1 & 686 & 337 & 6 & 2,446 & 7,907 & 23.5 \\
\hline H16 & Chusiac & 6.0 & M1 & 294 & 118 & 1 & 1,236 & 1,236 & 10.5 \\
\hline $\mathrm{H} 18$ & Jilotepeque Viejo & 11.0 & M1 & 539 & 250 & 5 & 2,778 & 12,581 & 50.3 \\
\hline $\mathrm{H} 20$ & Pueblo V. Chichaj & 8.0 & M1 & 392 & 168 & 1 & 1,589 & 1,589 & 9.5 \\
\hline $\mathrm{H} 25$ & Patzak & 10.0 & M1 & 490 & 222 & 2 & 2,003 & 3,832 & 17.3 \\
\hline $\mathrm{H} 27$ & Pueblo V. Canilla & 3.4 & M2 & 167 & 58 & 1 & 2,937 & 2,937 & 50.6 \\
\hline H30 & Moxquivil & 5.0 & A2 & 245 & 94 & 2 & 1,302 & 1,637 & 17.4 \\
\hline \multicolumn{10}{|c|}{ Oaxaca } \\
\hline O09 & Guiengola & 63.0 & $\mathrm{P} 1$ & 3,087 & 2,178 & 1 & 5,342 & 7,875 & 3.6 \\
\hline $\mathrm{O} 32$ & Mitla Palace* & 52.9 & $\mathrm{P} 2$ & 1,480 & 1,480 & 8 & e & 3,122 & 2.1 \\
\hline \multicolumn{10}{|c|}{ Peten/Belize } \\
\hline P09 & Topoxte & 3.2 & M2 & 157 & 54 & 1 & 1,603 & 1,603 & 29.7 \\
\hline $\mathrm{P} 12$ & Paxte & 2.8 & M2 & 137 & 46 & 2 & 528 & 1,082 & 23.5 \\
\hline \multicolumn{10}{|c|}{ Yucatan } \\
\hline Y10 & Mayapan* & 1010.0 & $\mathrm{P} 2$ & 17,000 & 17,000 & 1 & $\mathrm{e}$ & 56,054 & 3.3 \\
\hline Y16 & Tulum & 12.0 & $\mathrm{P} 1$ & 588 & 278 & 3 & 960 & 2,877 & 10.3 \\
\hline $\begin{array}{l}\text { text). } \\
\text { b Settle } \\
{ }^{\mathrm{c}} \text { Sourc } \\
\text { Smith } \\
{ }^{\mathrm{d}} \text { Estim } \\
{ }^{\mathrm{e}} \text { The ic }\end{array}$ & $\begin{array}{l}\text { Estimate } 1 \text { : based } \\
\text { ents marked with * } \\
\text { f data for settleme } \\
05 ; 2 \text { : data can be } \\
2 \text { is used to calcu } \\
\text { tity of the main pl }\end{array}$ & $\begin{array}{l}\text { assum } \\
\text { ere use } \\
\text { area: I } \\
\text { and in } \\
\text { e plaza }\end{array}$ & $\begin{array}{l}\text { n of cor } \\
\text { n the res } \\
\text { ublishec } \\
\text { ith ( } 201 \\
\text { ea per c } \\
\text { ear. }\end{array}$ & $\begin{array}{l}\text { ant dens } \\
\text { ssion to } \\
\text { latum; } M\end{array}$ & $\begin{array}{l}\text {; Estima } \\
\text { eate Popt } \\
\text { neasured }\end{array}$ & Ion $\mathrm{E}$ & $\begin{array}{l}\text { on assumpt } \\
\text { nate } 2 \text { (see } \\
\text { logist com }\end{array}$ & $\begin{array}{l}\text { of densi } \\
\text { xt for disc } \\
\text { unication }\end{array}$ & $\begin{array}{l}\text { tion (see } \\
\text { ion). } \\
\text { data in }\end{array}$ \\
\hline
\end{tabular}

(see Figure 4); details of measurement and data collection are provided in Smith (2017).

Most Late Postclassic cities and towns had well-defined formal plazas located in the center of the site. Larger cities often had subsidiary plazas built away from the central area. Because we are interested in the sum of all plaza activities in each settlement, we use the sum of the areas of all plazas in our analyses. The basal areas of shrines, platforms, or buildings located within plazas were subtracted from plaza areas, yielding the space available for movement and social interaction that we call the "plaza interaction area." Many of these settlements were capitals of city-states or other types of small polity. Although precise data are lacking, it is likely 


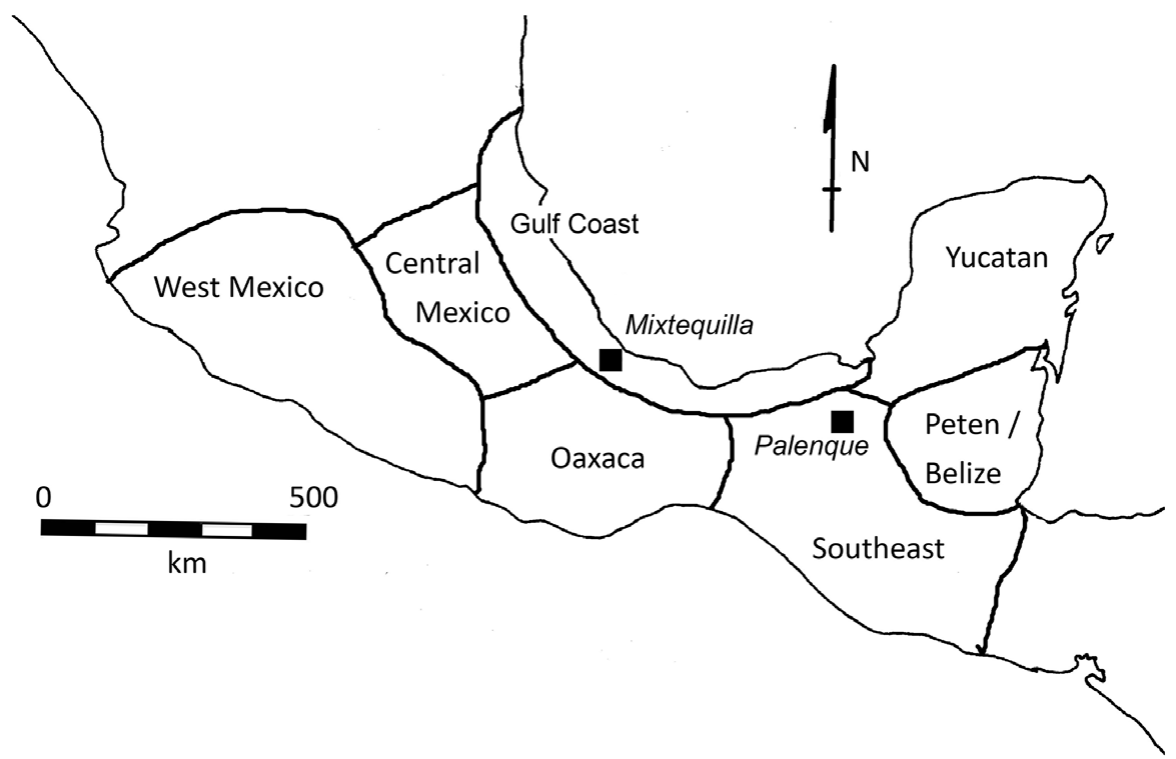

Figure 4. Map of Mesoamerica showing regions for the Late Postclassic sample of settlements. The Mixtequilla and Palenque regions are also shown. Map created by Michael E. Smith.
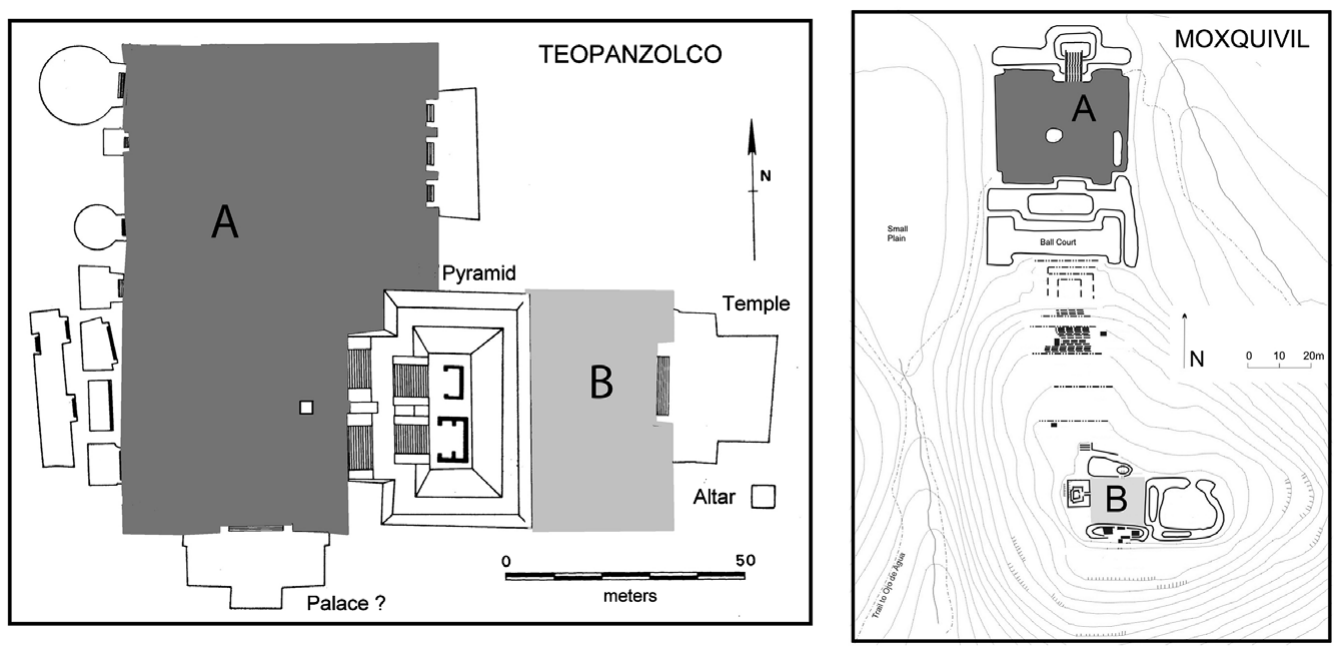

Figure 5. Plaza delineation in two Late Postclassic sites: Teopanzolco (Smith 2008:33) and Moxquivil (map provided by Elizabeth Paris). Maps redrawn showing plaza space by Michael E. Smith.

that the central plazas were designed and built early in the history of each settlement, and then subsidiary plazas were constructed at a later point as the city expanded. Figure 5 shows how plazas were measured in two sites: Teopanzolco (not part of this sample) and Moxquivil. The central plazas are labeled A, and secondary plazas are labeled B.
For most of the 30 sites in Table 1, we have measurements of their total settled area but lack independent population estimates. We calculate two separate population estimates for each site. The first (Estimate 1) is based on the common archaeological practice of multiplying site area by a density constant (Drennan et al. 2015:106). We use a constant of 50 persons per hectare, 
which is the median population density of Aztec cities (Smith 2008:152). The median is used instead of the mean because the mean is biased by the large population of Tenochtitlan. For four sites whose populations have been estimated independently of their area by archaeologists (Cuexcomate, Tenochtitlan, Mayapan, and Mitla Palace), we use those estimates. Estimate 2which we consider more realistic and accuratebuilds from the observation that human settlements generally increase in density as their populations grow. This pattern has been observed in a number of demographic analyses of both modern and premodern settlement systems, where settlement area exhibits a regular sublinear scaling relationship with respect to population (Cesaretti et al. 2016; Cook and Heizer 1968; Ortman et al. 2014; Ortman et al. 2016). The elasticity of the population-area relationship in these studies is similar to that found in contemporary urban systems, and it matches the value predicted by current models (Bettencourt 2013). Estimate 2 takes this general relationship into account. Specifically, we use Equation (1) in the case where $Y$ refers to the settled area. Rearranging this equation to solve for $N$, we obtain:

$$
N=\left(Y / Y_{0}\right)^{1 / \beta} .
$$

We use the subset of cases for which population is estimated independent of area (Cuexcomate, Tenochtitlan, Mayapan, Mitla Palace) to estimate $Y_{0}$ and $\beta$, using Equation (1), and then apply these figures to the settled area for each site to estimate the total population $N$ using Equation (3).

Therefore, two regression models were estimated, using different population estimates: model 1, which uses population Estimate 1 (based on the assumption of constant density); and model 2, which uses population Estimate 2 (based on the assumption that larger sites had denser populations than smaller sites). The number of observations $(n=30)$ is not very large but is sufficient to invoke the central limit theorem and thus estimate confidence intervals around the regression coefficient. The estimation results are shown in Table 2. Not surprisingly, the estimated regression coefficient for the effect of population size on plaza area differs between
Table 2. Regression Results.

\begin{tabular}{lcccc}
\hline & \multicolumn{2}{c}{ Late Postclassic: } & & \\
\cline { 2 - 4 } Parameter & Model 1 & Model 2 & Mixtequilla & Palenque \\
\hline constant & -4.51 & -3.54 & 5.04 & 6.50 \\
& $(0.554)$ & $(0.464)$ & $(2.526)$ & $(1.326)$ \\
$\beta$ & 0.55 & 0.44 & 0.61 & 0.40 \\
& $(0.076)$ & $(0.069)$ & $(0.444)$ & $(0.208)$ \\
$95 \%$ CI & {$[0.389$,} & {$[0.303$,} & & \\
& $0.702]$ & $0.586]$ & & \\
$\mathrm{R}^{2}$ & 0.68 & 0.66 & 0.61 & 0.44 \\
$\mathrm{n}$ & 30 & 30 & 10 & 11 \\
\hline
\end{tabular}

Note: Figures in parentheses are standard errors.

the two models- -0.55 for model 1 and 0.44 for model 2-but the $95 \%$ confidence intervals for the two estimated coefficients include each other. The proportion of the variability in plaza area explained by population size alone-about $65 \%$-is very similar in the models. The consistency of these results is somewhat remarkable given the simplicity of the model and the messiness of archaeological data.

\section{Classic Period South-Central Veracruz (Mixtequilla) Settlements}

Intensive settlement pattern research by the Proyecto Arqueológico La Mixtequilla (PALM) I and II, undertaken by Barbara Stark, forms the basis for our study of plazas and settlements in south-central Veracruz, Mexico (Mixtequilla). The plaza information was obtained from the centers and monumental complexes in a contiguous block of survey, or "main block" of the PALM projects, using detailed topographic maps (Figure 6). These data include the Classic period centers and related complexes of Cerro de las Mesas and Azuzules, in addition to minor monumental complexes and centers (see Table 3).

The original settlement study captures the majority of the centers that were identifiable within the delta of the lower Blanco (Stark 2001). The PALM survey covered $49 \mathrm{~km}^{2}$ for the main survey block and identified approximately 13 civic ceremonial complexes, including the 10 centers with formal plazas that were 
Table 3. Population and Plaza Area of Classic Period Mixtequilla Sites.

\begin{tabular}{lccccccc}
\hline Site & $\begin{array}{c}\text { Scale } \\
\text { Attraction }^{\mathrm{a}}\end{array}$ & $\begin{array}{c}\text { No. } \\
\text { Plazas }\end{array}$ & Plaza Area $^{\mathrm{b}}$ & Site Area $^{\mathrm{b}}$ & Population $^{\text {No. Mounds }}$ & $\begin{array}{r}\text { Plaza Area } \\
\text { per Capita }\end{array}$ \\
\hline La Compana & 500 & 1 & 1,616 & 79 & 269 & 48 & 6.0 \\
La Fraternidad & 500 & 1 & 3,817 & 79 & 263 & 47 & 14.5 \\
Tio Primo & 500 & 1 & 4,157 & 79 & 286 & 51 & 14.6 \\
Palmas Cuatas & $500^{\mathrm{c}}$ & 2 & 4,402 & 79 & 381 & 68 & 11.6 \\
Sabaneta & $500^{\mathrm{c}}$ & 1 & 4,518 & 79 & 84 & 15 & 53.8 \\
Moral & 500 & 1 & 4,690 & 79 & 274 & 49 & 17.1 \\
Mixtequilla & 500 & 1 & 6,360 & 79 & 224 & 40 & 28.4 \\
Zapotal Sur & 500 & 1 & 7,203 & 79 & 314 & 56 & 23.0 \\
Azuzules & 500 & 1 & 7,380 & 79 & 1,266 & 226 & 5.8 \\
Cerro de las Mesas & $750-2,000$ & 5 & 45,298 & 1,257 & 4,480 & 800 & 10.1 \\
\hline
\end{tabular}

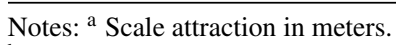

${ }^{\mathrm{b}}$ Plaza area measured in square meters; site area measured in hectares.

${ }^{\mathrm{c}}$ None; default value of $500 \mathrm{~m}$.

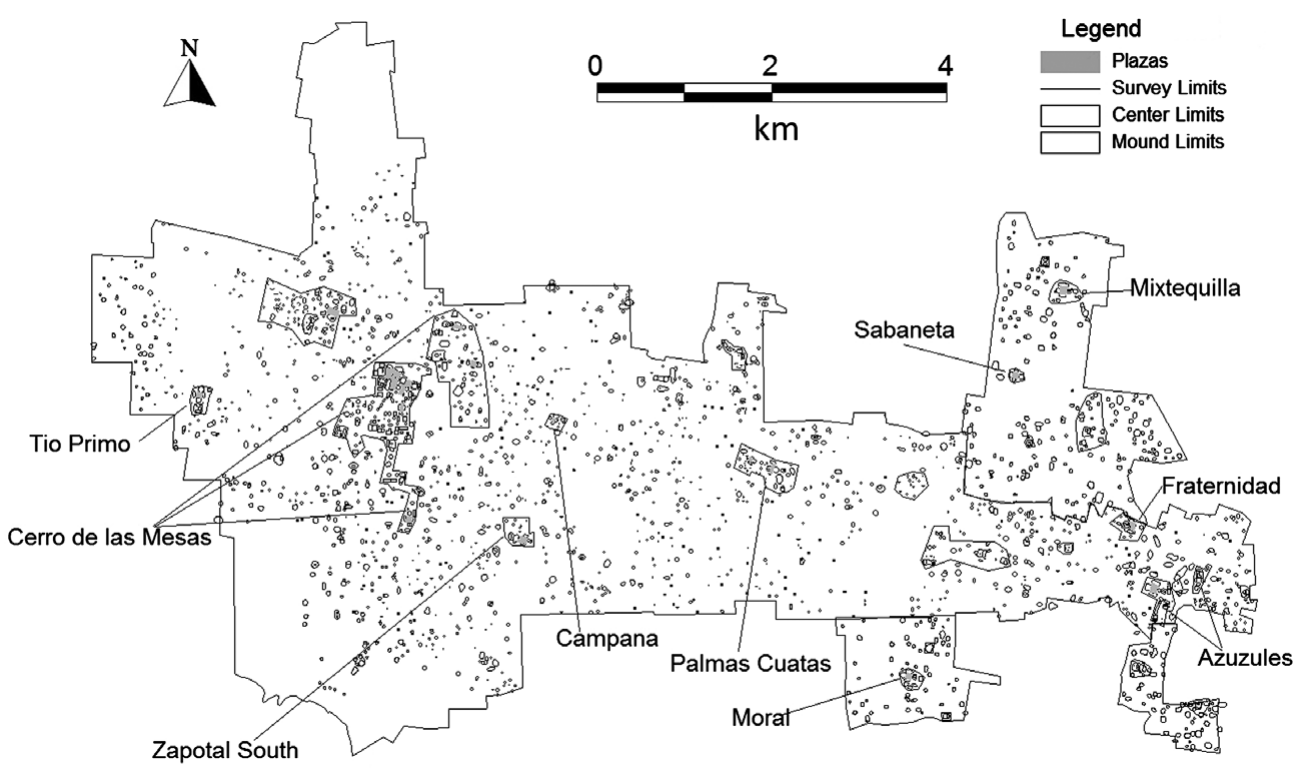

Figure 6. Mixtequilla survey block map. Map created by Alanna Ossa using PALM data provided by Dr. Barbara L. Stark.

used in this study (Stark 1999). For the Classic period Mixtequilla, formal plazas were typically configured in a recognizable "standard plan" that included a conical mound accompanied by two elongated mounds forming a plaza with a ball court opposite the conical mound (Daneels 2002), although some locally identified variants of this plan exist (Stark 2016). Two of the three complexes not used in our study had no formal plaza space and may not be public complexes (Ossa 2014). The third complex was Postclassic, an era excluded from our study.
The largest contiguous block or "main block" of the settlement study captured all of the identifiable centers. As such, these centers can be considered a single population within a defined spatial area. The status of these sites as a population affects their statistical treatment (see below) and allows us to do more with them.

Only general data are possible for plazas on a very broad time scale, encompassing the Classic/Late Classic (AD 300-900) period. We use the plan data obtained from the contour maps and GPS footprints to establish plaza area. We 
recognize that these areas could have changed during their use of several hundred years and that a certain amount of mound erosion-based error is also possible.

Population estimates for south-central Veracruz were based on a Monte Carlo simulation that tested the existence and scale (where possible) of individual domestic mound associations with centers (Ossa 2014). The domestic mounds are remnants of residential occupation based on excavations and multiple years of intensive survey (Stark 1999, 2001). The simulation allowed us to identify the scale at which residences were associated with centers by measuring the highest densities of residences. Since the region is characterized by a distribution of residences without easily identified drop-offs that could mark the edges of center-associated populations, the simulated residential association scale provided a quantifiable settlement population boundary for most, though not all, of the centers in this study. Residences were assigned to the closest center based on the identified scale. For those centers where settlement attraction scales were not identified, a scale was selected based on size. Once a scale was identified/selected, all residential mounds within each center buffer were tabulated at 5.6 persons per individual mound to come up with a population estimate per center (Table 3 ). The figure of 5.6 persons per household is taken from Kolb's (1985) thorough study of Mesoamerican household size.

Given that the Classic period occupation is the longest, the majority of residences used in this analysis probably date to the Classic period, although their exact contemporaneity is unknown. Site areas were calculated based on the scale of settlement association identified by the original simulation (Ossa 2014). Finally, the location of Azuzules near the survey boundary means that some boundary effect in measuring settlement (and therefore population) is possible, although ground reconnaissance in the areas south of Azuzules indicate that residential mounds are not found in abundance in that area.

The decision to treat the data set for the Classic period Mixtequilla settlements as a population makes it possible to estimate $\beta$ notwithstanding the small number of observations (therefore a confidence interval around the estimated regres- sion coefficient is not reported). The estimated coefficient is 0.61 , indicating a sublinear relationship between population size and plaza area. The larger size of the coefficient relative to the Postclassic sites (Table 2) indicates that the per capita plaza area declines more slowly with population size in the Mixtequilla population. The $R^{2}$ value of 0.63 is very similar to that for the Postclassic cities data, and again it is remarkable that over $60 \%$ of the variability in the area of plazas in the Mixtequilla centers is explained by population size alone.

\section{The Palenque Region in the Classic Period}

Our third case consists of the Classic period Maya city of Palenque and a group of 10 nearby sites from a regional survey directed by Rodrigo Liendo Stuardo (2002, 2011). Palenque was a major urban center renowned for its architecture, art, and hieroglyphic inscriptions (Marken 2007). Liendo Stuardo surveyed an area of $470 \mathrm{~km}^{2}$ around Palenque. He published tables of data that include areal extent and population estimates (based on counts of house mounds) of several hundred sites (Liendo Stuardo 2011:25-33). The sites are classified into five types that form an ordinal scale of decreasing architectural complexity. Our data are from a table of the sites with civic-ceremonial architecture published in Liendo Stuardo (2014:117). Sites with civicceremonial architecture are classified as Category 5 in the survey typology (Liendo Stuardo 2011:25-33); these sites are further subdivided into two "ranks." There are two regional capitals (Rank 1)—Palenque and Chinikiha_-and nine minor civic centers (Rank 2).

These sites can be considered a population following the same logic applied to the Mixtequilla sites; they consist of all of the centers present within a defined spatial zone (survey area). The sites and measurements are shown in Table 4. Site populations were estimated by Liendo Stuardo and colleagues (2014:117) by multiplying the number of house mounds by the same constant of 5.6 as was applied in the Mixtequilla, maintaining internal consistency. Liendo Stuardo also provides an illustration of how the main plaza at Chinikiha was delimited for purposes of measuring its area (Liendo Stuardo et al. 2014:113). We remeasured this plaza, 
Table 4. Population and Plaza Area of Classic Period Palenque Region Sites.

\begin{tabular}{lcrrc}
\hline Site Name & Rank & $\begin{array}{r}\text { Plaza } \\
\text { Area }^{\mathrm{a}}\end{array}$ & Pop. & $\begin{array}{r}\text { Plaza Area } \\
\text { per Capita }\end{array}$ \\
\hline Palenque & 1 & 40,840 & 8,389 & 4.9 \\
Chinikiha & 1 & 12,965 & 1,960 & 6.6 \\
Xupa & 2 & 5,577 & 78 & 71.5 \\
El Lacandon & 2 & 3,004 & 403 & 7.5 \\
La Cascada & 2 & 10,188 & 190 & 53.6 \\
La Providencia & 2 & 3,639 & 84 & 43.3 \\
Nututun & 2 & 4,208 & 456 & 9.2 \\
Santa Isabel & 2 & 5,375 & 230 & 23.4 \\
Sulusum & 2 & 1,773 & 106 & 16.7 \\
Boca Chin & 2 & 17,499 & 106 & 165.1 \\
El Retiro & 2 & 3,682 & 174 & 21.2 \\
\hline
\end{tabular}

Notes: Data from Liendo Stuardo et al. (2014:117).

${ }^{\mathrm{a}}$ Area in square meters.

using the protocols established for measuring Postclassic plaza size, and our result-13,034 $\mathrm{m}^{2}$ after removing the area of a structure in the center of the plaza-is within $0.53 \%$ of Liendo Stuardo's figure. On this basis we conclude that Liendo Stuardo's plaza area measurements are equivalent to our measures of "interaction area" in the Postclassic sample described above.

As in the Mixtequilla, the decision to treat the data set for the Classic period Palenque area cities as a population makes it possible to estimate $\beta$ notwithstanding the small number of observations. The estimated coefficient is 0.40 , very close to the value for population Estimate 2 of the Postclassic sample. The $R^{2}$ value of 0.44 is smaller than that for our other cases, partially due to the small number of observations, but it does show that population size is an important determinant of plaza area in the Palenque survey region.

\section{Discussion}

We have reported quantitative relationships between population size and plaza area for three separate groups of Mesoamerican settlements. One group is a sample of 30 Late Postclassic settlements from throughout Mesoamerica, and the other two are regional urban systems from the Classic period. The confidence intervals for the estimated regression coefficients for the two models using the Postclassic data include 0.4, and thus the results for Postclassic and Palenque urban systems are consistent with a value of $\beta$ of 0.4 . This can be interpreted as indicating that a $1 \%$ increase in population was associated with a $0.4 \%$ increase in plaza area. The total area devoted to plazas in all three urban systems under consideration did indeed increase with population size but in a manner considerably less than proportionally. The similarity in estimated $\beta$ values for two of the sets of observations suggests that the underlying social forces responsible for plaza size may have been similar in these cases. The divergent value for the Mixtequilla sites may point to differences in how those plazas were used relative to the other two cases we examined.

Another way of expressing the sublinear scaling relationships listed in Table 2 is to examine the plaza space per capita in comparison with settlement population. This relationship is shown-using logarithms of the data-in Figure 7. Two alternative explanations for the quantitative relationship between population size and plaza area can be contemplated. First, our results suggest plazas could not have held mass spectator ceremonies in which the entire urban population participated at the same time. If this were the case, one would expect a linear scaling relationship, in which larger towns would have the same amount of plaza space per capita as smaller settlement systems. The fact that larger settlements had far less plaza area per capita than smaller settlements in all three groups lends support to the notion that plazas were designed for a variety of (likely periodic) activities, rather than being designed specifically to hold the entire population of the city in mass spectator ceremonies

A second, alternative, explanation for our results is that when cities and towns were initially planned and built, their plazas were intended to hold the entire urban population in mass spectator ceremonies. But then as the settlements grew, the plazas remained the same size and thus the per capita area would have decreased through time. It clearly would have been difficult to expand the main central plaza as a settlement grew, given that most plazas were hemmed in by pyramids, palaces, and ball courts. But if plaza size needed to keep up with population size (for whatever reason), the easiest way to do this was to add smaller, subsidiary plazas, 


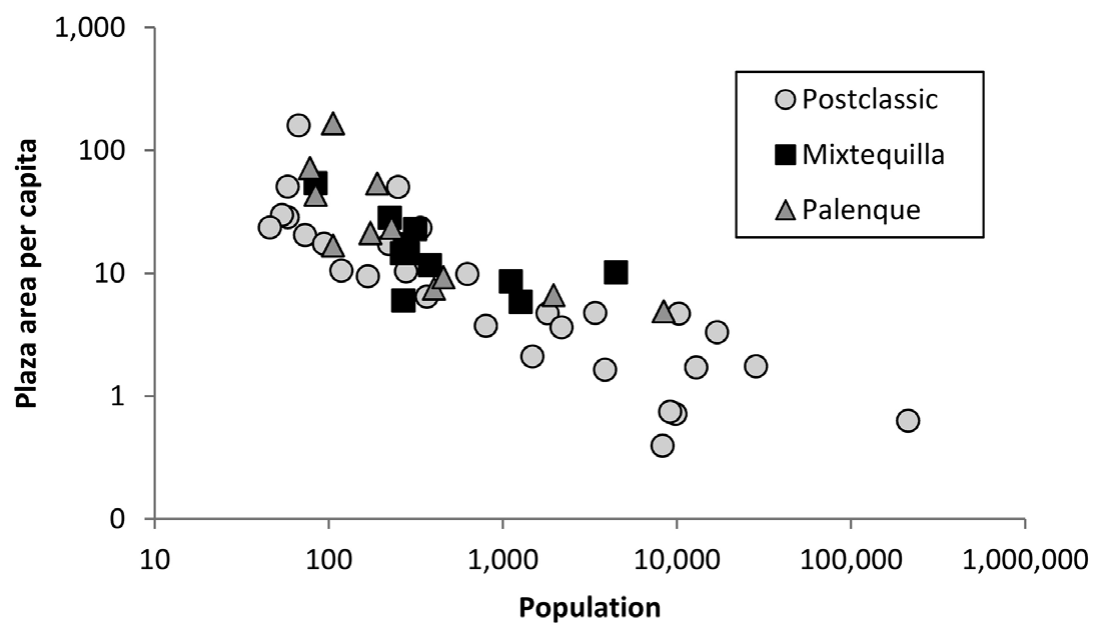

Figure 7. Graph of plaza area per capita against population for the three data sets. Note the logarithmic scales of the axes. Graph created by Michael E. Smith.

often at some distance from the central plaza. In Inomata's (2006a:816) table of plaza areas, he lists six plazas in addition to the Great Plaza at Tikal, five plazas in addition to the Great Plaza at Copan, and one subsidiary plaza at Aguateca. We should note that such subsidiary plazas would have not been effective for mass spectator ceremonies, which require the entire population be together in one location in order to experience the same event. The presence of such plazas thus provides another argument against the notion that plazas were designed primarily for such mass ceremonies. Most large Mesoamerican cities are similar in having a single central plaza plus a number of smaller plazas. Although the lack of firm dates on urban expansion at these and other Mesoamerican cities prevents a definitive test of the hypothesis that subsidiary plazas were built after the central plaza, the fact that the relationship between population and total plaza space is similar across three separate data sets, and across settlements inhabited for differing periods of time, argues against this alternative explanation for the sublinear scaling of plaza size.

Another possibility is that the sublinear relationships between estimated population and plaza space that we observe are an artifact of our population estimates. We think otherwise for three reasons. First, errors derived from the application of any constant factor, such as the number of persons per household, would have no impact on the exponent of the scaling relation and would only affect the coefficient. Second, in all cases, the exponent of the scaling relation is so much less than one that, in order to make the relation linear, our population estimates would have to be too large by about a power of two. It is highly unlikely that these estimates are systematically off by so much, and so there is no realistic way to translate our results into a linear relationship. Third, it is important to emphasize that our analysis examines the average relationship between population and plaza space at logarithmic scales, so even substantial errors in the estimates we use for specific sites should not have much impact so long as these errors are unstructured and do not expand exponentially with scale. For example, suppose that our estimate for the population of Tenochtitlan (ca. 200,000) is twice as large as it should be. The logarithm (base 10) of 100,000 is 5 , whereas the $\log$ (base 10) of 200,000 is 5.3. So even if Tenochtitlan were only half as large as the commonly cited value that we used, this would reduce the log-transformed value for the population of this site by only $6 \%$. This example shows that imprecision in estimates at linear scales is not a significant problem when one is working at exponential scales.

Following these considerations, we conclude that the regression analyses presented in this article provide evidence against Inomata's 
suggestion that Maya public plazas (and, by extension, other Mesoamerican plazas) were planned and built primarily to accommodate the entire urban population simultaneously in mass spectator ceremonies. This does not mean that such ceremonies did not take place in Maya plazas; by analogy with Aztec ethnohistory, it would be expected that such ceremonies did occasionally take place. But at the Aztec capital Tenochtitlan at least, the per capita plaza area of $0.61\left(\mathrm{~m}^{2}\right.$ per person) suggests that it is unlikely that the entire urban population ever gathered in the various city plazas at the same time (despite the claims of the chronicler Diego Durán, cited above). For smaller settlements, with larger per capita plaza areas, it is entirely possible that the entire population did gather in plazas for a particular ceremony. Our results are consistent with the notion that Mesoamerican plazas were multifunctional places intended to host a variety of periodic activities, from marketing to ritual, although they should not be seen as providing direct empirical support for this interpretation. We acknowledge a series of caveats about the plaza data (chronologies are rough, maps may not all be of the same accuracy) and about our samples (they are not large), but despite these potentially confounding factors, we have identified consistent and empirically robust patterns.

\section{Conclusions}

Our identification of regular quantitative relationships between plaza size and population may seem surprising at first glance. These Mesoamerican settlements not only experienced different sociological, cultural, economic, and technological contexts but each also had experienced hundreds of years of growth and change. Over the course of their existence each settlement likely experienced periods of growth, stasis, and decline, and witnessed major demographic, economic, political, and spatial transformations. From this rich historical perspective, one might expect the relationship between resident population and plaza area to have been exceptional and unique in each Mesoamerican settlement. On one level this is true, as in no case do all the settlements in a group line up along the best-fit line. Yet our data still show that on average there is a consistent quantitative relationship between population and plaza area within individual settlement systems, and a consistent relationship across two of the three systems considered in this article. These results suggest that plazas were used for similar suites of activities in some kind of regular patterns in the Palenque and Late Postclassic urban systems, and that plazas in the Mixtequilla system also exhibit regular patterns, although with different activities or participants than the other two systems.

Our results make sense within a new perspective that has emerged from empirical studies and theoretical considerations in a variety of disciplines (economics, geography, engineering, and complex systems) that shows how contemporary cities share certain predictable quantitative properties. A number of quantitative urban variables-surface area, amount of infrastructure, and a broad series of both positive and negative social outcomes - scale with population in a predictable manner (Bettencourt 2013; Youn et al. 2016). Our work has documented that these same quantitative scaling relationships also hold, not only for cities before the modern era (Cesaretti et al. 2016; Ortman et al. 2014; Ortman et al. 2016) but also for village-level settlement systems (Ortman and Coffey 2015).

The results presented in the current article do not match any of the empirical scaling relationships previously identified for contemporary cities (Bettencourt 2013), and there is no current quantitative model that explains the specific scaling exponent of 0.40 that we observe in two of the groups. The coefficient for the Mixtequilla area- 0.61 - is within the range of known values for the scaling relationship of both land area and infrastructure length with population (Bettencourt 2013), but we do not know of behavioral models that would associate plaza area with either of those two urban variables.

Additional empirical studies of the relationship between population and public gathering spaces, perhaps in societies where the uses of such spaces are more directly attested, will likely be necessary before a reasonable formal model of the relationship can be developed. For now, we simply emphasize that the sublinear relationship between plaza area and population we observe 
across diverse data sets from Mesoamerica suggests: (1) that there are general patterns in the relationship between population and the built environment that appear to reflect the typical use patterns of plazas, and (2) Mesoamerican plazas could not have been designed or maintained specifically to accommodate mass spectator ceremonies involving the simultaneous participation of the entire urban population.

Acknowledgments. We thank a number of colleagues for help during the preparation of this article. ASU undergraduate Alexandra Norwood measured the plaza sizes for the Postclassic sample, and Shelby Manney helped with the sizes of plazas at Calixtlhahuaca. Frances Berdan provided assistance with citations for Aztec ceremonies, and Rodrigo Liendo Stuardo provided information and advice on the Palenque data. We thank the following colleagues for providing unpublished data on site population and plaza size, reported in our Table 1: Elizabeth Paris (Moxquivil), Marilyn Masson and Timothy Hare (Mayapan), and Marcie Venter (Totogal). Unpublished PALM contour maps and settlement pattern data are used with the permission of Barbara Stark. We thank project members who labored on the contour maps of centers in the Mixtequilla, especially Lynette Heller. We thank Barbara Stark, Scott Ortman, and Luis Bettencourt for helpful comments and suggestions on an earlier draft. We also thank the four anonymous reviewers, whose comments have improved this manuscript.

Data Availability Statement. The published materials from Postclassic and Classic period centers in Mesoamerica are available in the cited publications. Unpublished information on site population and plaza size is reported in the tables associated with this manuscript. Electronic versions of the PALM data set from Barbara Stark can also be found online at tDAR, the Digital Archaeological Record.

\section{References Cited}

Anders, Ferdinand, Maarten E.R.G.N. Jansen, Luis Reyes García, and Aurora Pérez Jiménez

1991 Códice Borbónico: El libro del Cihuacóatl, homenaje para el año del Fuego Nuevo. Códices Mexicanos, Vol. 3. Sociedad Estatal Quinto Centenario, Madrid; Akademische Druck- und Verlagsanstalt, Graz; Fondo de Cultura Económica, Mexico City.

Andrews, George F.

1975 Maya Cities: Placemaking and Urbanization. University of Oklahoma Press, Norman.

Beals, Ralph L.

1975 The Peasant Marketing System of Oaxaca, Mexico. University of California Press, Los Angeles.

Berdan, Frances F., Marilyn A. Masson, Janine Gasco, and Michael E. Smith

2003 An International Economy. In The Postclassic Mesoamerican World, edited by Michael E. Smith and Frances F. Berdan, pp. 96-108. University of Utah Press, Salt Lake City.
Bettencourt, Luís M. A.

2013 The Origins of Scaling in Cities. Science 340: 1438-1441.

Blanton, Richard E.

1996 The Basin of Mexico Market System and the Growth of Empire. In Aztec Imperial Strategies, edited by Frances F. Berdan, Richard E. Blanton, Elizabeth H. Boone, Mary G. Hodge, Michael E. Smith, and Emily Umberger, pp. 47-84. Dumbarton Oaks, Washington, DC.

Brock, W. A.

1999 Scaling in Economics: A Reader's Guide. Industrial and Corporate Change 8:409-446.

Brown, James H., Geoffrey B. West, and Brian J. Enquist

2000 Scaling in Biology: Patterns and Processes, Causes, and Consequences. In Scaling in Biology, edited by James H. Brown and Geoffrey B. West, pp. 1-24. Oxford University Press, New York.

Canuto, Marcello A., James P. Charton, and Ellen E. Bell

2010 Let No Space Go to Waste: Comparing the Uses of Space Between Two Late Classic Centers in the El Paraíso Valley, Copan, Honduras. Journal of Archaeological Science 37:30-41.

Cap, Bernadette

2012 "Empty" Spaces and Public Places: A Microscopic View of Chan's Late Classic West Plaza. In Chan: An Ancient Maya Farming Community, edited by Cynthia Robin, pp. 150-172. University Press of Florida, Gainesville.

Carballo, David M.

2012 Public Ritual and Urbanization in Central Mexico: Plaza and Temple Offerings from La Laguna, Tlaxcala. Cambridge Archaeological Journal 22:329-352.

Carneiro, Robert L.

2000 The Transition from Quantity to Quality: A Neglected Causal Mechanism in Accounting for Social Evolution. Proceedings of the National Academy of Sciences 97:12926-12931.

Cesaretti, Rudolf, José Lobo, Luís M. A. Bettencourt, Scott G. Ortman, and Michael E. Smith

2016 Population-Area Relationship for Medieval European Cities. PLoS ONE 11(10):e0162678. DOI:10. 1371/journal.pone.0162678, accessed September 5, 2017.

Chase, Arlen F., Diane Z. Chase, Richard Terry, Jacob Horlacher, and Adrian S. Z. Chase

2015 Markets Among the Ancient Maya: The Case of Caracol, Belize. In The Ancient Maya Marketplace: The Archaeology of Transient Space, edited by Eleanor M. King, pp. 226-250. University of Arizona Press, Tucson.

Chave, Jérome, and Simon Levin

2003 Scale and Scaling in Ecological and Economic Systems. Environmental and Resources Economics 26:527557.

Cobb, Charles R., and Brian M. Butler

2017 Mississippian Plazas, Performances, and Portable Histories. Journal of Archaeological Method and Theory 24(3):676-702.

Coffey, William J.

1979 Allometric Growth in Urban and Regional SocialEconomic Systems. Canadian Journal of Regional Science 11(1):49-65.

Cook, Scott, and Martin Diskin (editors)

1976 Markets in Oaxaca. University of Texas Press, Austin. 
Cook, Sherburne F., and Robert F. Heizer

1968 Relationships among Houses, Settlement Areas, and Population in Aboriginal California. In Settlement Archaeology, edited by K. C. Chang, pp. 79-116. Yale University Press, New Haven, Connecticut.

Dahlin, Bruce H., Christopher T. Jensen, Richard E. Terry, David R. Wright, and Timothy Beach

2007 In Search of an Ancient Maya Market. Latin American Antiquity 18:363-384.

Daneels, Annick

2002 El patrón de asentamiento del período clásico en la cuenca baja del río Cotaxtla, centro de Veracruz: Un estudio de caso de desarrollo de sociedades complejas en tierras bajas tropicales. $\mathrm{PhD}$ dissertation, Instituto de Investigaciones Antropológicas, Universidad Nacional Autónoma de México, Mexico City.

Demarest, Arthur A.

1992 Ideology in Ancient Maya Cultural Evolution: The Dynamics of Galactic Polities. In Ideology and Pre-Columbian Civilizations, edited by Arthur A. Demarest and Geoffrey W. Conrad, pp. 135158. School of American Research Press, Santa Fe, New Mexico.

Díaz del Castillo, Bernal

1956 The Discovery and Conquest of Mexico. Translated by A. P. Maudslay. Farrar, Straus, and Cudahy, New York.

Drennan, Robert D., C. Adam Berrey, and Christian E. Peterson

2015 Regional Settlement Demography in Archaeology. Eliot Werner Publications, Bristol, Connecticut.

Durán, Fray Diego

1971 Book of the Gods and Rites and The Ancient Calendar. Translated by Fernando Horcasitas and Doris Heyden. University of Oklahoma Press, Norman.

Fulton, Kara A., E. Christian Wells, and Donald A. Storer

2017 Ritual or Residential: An Integrated Approach to Geochemical Prospection for Understanding the use of Plaza Spaces at Palmarejo, Honduras. Archaeological and Anthropological Sciences 9(6):1059-1076.

Gade, Daniel W.

1976 The Latin American Central Plaza as a Functional Space. Proceedings of the Conference of Latin Americanist Geographers 5:16-23.

Geertz, Clifford

1980 Negara: The Theatre State in Nineteenth-Century Bali. Princeton University Press, Princeton, New Jersey.

Glaeser, Edward L., Bruce I. Sacerdote, and Jose A. Scheinkman

2003 The Social Multiplier. Journal of the European Economic Association 1:345-353.

González Rul, Francisco

1998 Urbanismo y arquitectura en Tlatelolco. Serie Arqueología, Colección Científica, Vol. 346. Instituto Nacional de Antropología e Historia, Mexico City.

Hassig, Ross

1985 Trade, Tribute, and Transportation: The SixteenthCentury Political Economy of the Valley of Mexico. University of Oklahoma Press, Norman.

Inomata, Takeshi

2006a Plazas, Performers, and Spectators: Political Theaters of the Classic Maya. Current Anthropology 47:805-842.

2006b Politics and Theatricality in Maya Society. In Archaeology of Performance: Theaters of Power, Community, and Politics, edited by Takeshi Inomata and
Lawrence S. Coben, pp. 187-222. Altamira, Walnut Creek, California.

Jones, Christopher

2015 The Marketplace at Tikal. In The Ancient Maya Marketplace: The Archaeology of Transient Space, edited by Eleanor M. King, pp. 67-89. University of Arizona Press, Tucson.

Kolb, Charles C.

1985 Demographic Estimates in Archaeology: Contributions from Ethnoarchaeology on Mesoamerican Peasants. Current Anthropology 26:581-600.

Kostof, Spiro

1991 The City Shaped: Urban Patterns and Meanings Through History. Bullfinch, Boston, Massachusetts.

Lewis, Oscar

1951 Life in a Mexican Village: Tepoztlan Restudied. University of Illinois Press, Urbana.

Liendo Stuardo, Rodrigo

2002 La organización de la producción agrícola en un centro Maya del clásico. Patrón de asentamiento en la región de Palenque/The Organization of Agricultural Production at a Classic Maya Center: Settlement Patterns in the Palenque Region, Chiapas, Mexico. Instituto Nacional de Antropología e Historia, Mexico City; University of Pittsburgh, Pittsburgh, Pennsylvania.

2011 B'aakal: Arqueología de la Región de Palenque, Chiapas, México, Temporadas 1996-2006. Paris Monographs in American Archaeology 26. BAR International Series Vol. 2203. British Archaeological Reports, Oxford.

Liendo Stuardo, Rodrigo, Javier López Mejía, and Arianna Campisani

2014 The Social Construction of Public Spaces at Palenque and Chinikihá, Mexico. In Mesoamerican Plazas: Arenas of Community and Power, edited by Kenchiro Tsukamoto and Takeshi Inomata, pp. 108120. University of Arizona Press, Tucson.

Marken, Damien B. (editor)

2007 Palenque: Recent Investigations at the Classic Maya Center. AltaMira Press, Lanham, Maryland.

Masson, Marilyn A., and David A. Friedel

2013 Wide Open Spaces: A Long View of the Importance of Maya Market Exchange. In Merchants, Markets, and Exchange in the Pre-Columbian World, edited by Kenneth G. Hirth and Joanne Pillsbury, pp. 201-228. Dumbarton Oaks, Washington, DC.

Matos Moctezuma, Eduardo

2015 ¿Habia un mercado frente al palacio de Moctezuma? Arqueología Mexicana 133:88-89.

McBryde, Felix W.

1947 Cultural and Historical Geography of Southeast Guatemala. Institute of Social Anthropology Publication 4. Smithsonian Institution, Washington, DC.

Moore, Jerry D.

1996 Architecture and Power in the Ancient Andes: The Archaeology of Public Buildings. Cambridge University Press, New York.

Ortman, Scott G., Andrew H. F. Cabaniss, Jennie O. Sturm, and Luís M. A. Bettencourt

2014 The Pre-History of Urban Scaling. PLOS ONE 9 (2):e87902. DOI:https://doi.org/10.1371/journal.pone. 0087902, accessed September 5, 2017.

Ortman, Scott G., and Grant D. Coffey

2015 Universal Scaling: Evidence from Village-Level Societies. SFI Working Paper, Vol. 15-10-044. Santa $\mathrm{Fe}$ Institute, Santa $\mathrm{Fe}$, New Mexico. Electronic 
document, https://www.santafe.edu/research/results/ working-papers/universal-scaling-evidence-fromvillage-level-soci, accessed September 5, 2017.

Ortman, Scott G., Kaitlyn E. Davis, José Lobo, Michael E. Smith, Luis M. A. Bettencourt, and Aaron Trumbo

2016 Settlement Scaling and Economic Change in the Central Andes. Journal of Archaeological Science 73:94-106.

Ossa, Alanna

2014 Plazas in Comparative Perspective in South-Central Veracruz from the Classic to the Postclassic Period (A.D. 300-1350). In Mesoamerican Plazas: Arenas of Community and Power, edited by Kenchiro Tsukamoto and Takeshi Inomata, pp. 130-146. University of Arizona Press, Tucson.

Rapoport, Amos

1990 Systems of Activities and Systems of Settings. In Domestic Architecture and the Use of Space: An Interdisciplinary Cross-Cultural Study, edited by Susan Kent, pp. 9-20. Cambridge University Press, New York.

Robin, Cynthia, Laura Kosakowsky, Angela Keller, and James Melerhoff

2014 Leaders, Farmers, and Crafters: The Relationship between Leading Households and Households across the Chan Community. Ancient Mesoamerica 25:371387.

Rojas, José Luis de

2012 Tenochtitlan: Capital of the Aztec Empire. University Press of Florida, Gainesville.

Sahagún, Fray Bernardino de

1950-1982 Florentine Codex, General History of the Things of New Spain. 12 books. Translated and edited by Arthur J.O. Anderson and Charles E. Dibble. School of American Research, Santa Fe, New Mexico; University of Utah Press, Salt Lake City.

1993 Primeros Memoriales. Facsimile ed. Edited by Ferdinand Anders. University of Oklahoma Press, Norman.

Seler, Eduard

1927 Einige Kapitel aus dem Geschichtswerke des Fray Bernardino de Sahagún aus den Aztekischen übersetzt. Edited by Caecilie Seler-Sachs. Strecker und Schroeder, Stuttgart.

Smith, Michael E.

2005 City Size in Late Postclassic Mesoamerica. Journal of Urban History 31:403-434.

2007 Form and Meaning in the Earliest Cities: A New Approach to Ancient Urban Planning. Journal of Planning History 6(1):3-47.

2008 Aztec City-State Capitals. University Press of Florida, Gainesville.

2011 Empirical Urban Theory for Archaeologists. Journal of Archaeological Method and Theory 18:167192.

2012 The Aztecs. 3rd ed. Blackwell Publishers, Oxford.
2017 Thirty Postclassic Mesoamerican Cities. Social Reactors Project datasets, The Digital Archaeological Record (tDAR). DOI:10.6067/XCV8CR5VSB, accessed September 6, 2017.

Speer, Albert

1985 Architecture, 1932-1942. Archives d'Architecture Moderne, Brussels.

Stark, Barbara L.

1999 Formal Architectural Complexes in South-Central Veracruz, Mexico: A Capital Zone? Journal of Field Archaeology 26:197-226.

2001 Classic Period Mixtequilla, Veracruz, Mexico: Diachronic Inferences from Residential Investigations. Monograph 12. University at Albany, Albany, New York.

2016 Central Precinct Plaza Replication and Corporate Groups in Mesoamerica. In Alternative Pathways to Complexity: A Collection of Essays on Architecture, Economics, Power, and Cross-Cultural Analysis in Honor of Richard E. Blanton, edited by Lane F. Fargher and Verenice Y. Heredia Espinoza, pp. 105-130. University Press of Colorado, Boulder.

Terry, Richard E., Daniel A. Bair, and Eric G. Coronel

2015 Soil Chemistry in the Search for Ancient Maya Marketplaces. In The Ancient Maya Marketplace: The Archaeology of Transient Space, edited by Eleanor M. King, pp. 226-250. University of Arizona Press, Tucson.

Thompson, Victor D.

2009 The Mississippian Production of Space through Earthen Pyramids and Public Buildings on the Georgia Coast, USA. World Archaeology 41:445-470.

Tsukamoto, Kenchiro, and Takeshi Inomata (editors)

2014 Mesoamerican Plazas: Arenas of Community and Power. University of Arizona Press, Tucson.

Youn, Hyejin, Luís M. A. Bettencourt, José Lobo,

Deborah Strumsky, Horacio Samaniego, and Geoffrey B. West

2016 Scaling and Universality in Urban Economic Diversification. Journal of the Royal Society Interface 13(114):20150937.

\section{Note}

1. One historical case of a plaza designed for a specific spacing among participants in mass spectator ceremonies is the Zeppelin Field in Nuremberg, Germany, designed and built by Albert Speer for Nazi rallies 1933-1938. Speer (1985:165) wrote that he designed the parade grounds at $290 \mathrm{~m}$ by $312 \mathrm{~m}$ to hold 90,000 persons, which works out to a spacing of $1.005 \mathrm{~m}^{2}$ per person.

Submitted October 16, 2016; Revised January 28, 2017;

Accepted August 9, 2017 